\section{Reported Deaths}

\section{Robert K. Soost}

Dr. Robert K. Soost, 88, Professor Emeritus in the Department of Botany and Plant Sciences, University of California (UC) Riverside, died on 8 Mar. 2009.

Dr. Soost was internationally known for his work in citrus breeding. His research included a focus on nuclear embryony and the cytology of citrus, and he was considered a world authority on citrus genetics and breeding, consulting in other countries, training visiting scientists from foreign nations, and speaking at international conferences.

Dr. Soost and colleague Dr. James Cameron developed the Oroblanco and Melogold grapefruits, which were patented by the university in 1981 and 1986, respectively, and received wide distribution among California growers, and the Pixie and Gold Nugget mandarins. The Pixie has become a favorite for backyard planting, while the Gold Nugget, which was released in 2000, was both seedless and had exceptional sweetness and flavor.

Born on 13 Nov. 1920 in Sacramento, Dr. Soost attended Sacramento Junior College, and in 1942 graduated from UC-Berkeley. He served in the Army Signal Corps during WWII. In 1949 he earned his PhD in plant genetics from UC-Davis. Dr. Soost was a member of Phi Beta Kappa and Sigma Xi, and a Fellow of the American Association for the Advancement of Science and ASHS. He was a lifetime emeritus of ASHS, where he had been a member for more than 50 years.

Dr. Soost joined the staff of the Citrus Experiment Station in 1949 as a junior geneticist. In 1961, seven years after the Riverside station had turned into a university, he was named to a teaching post and now bore the title Associate Professor of Genetics and Associate Geneticist; he reached full rank

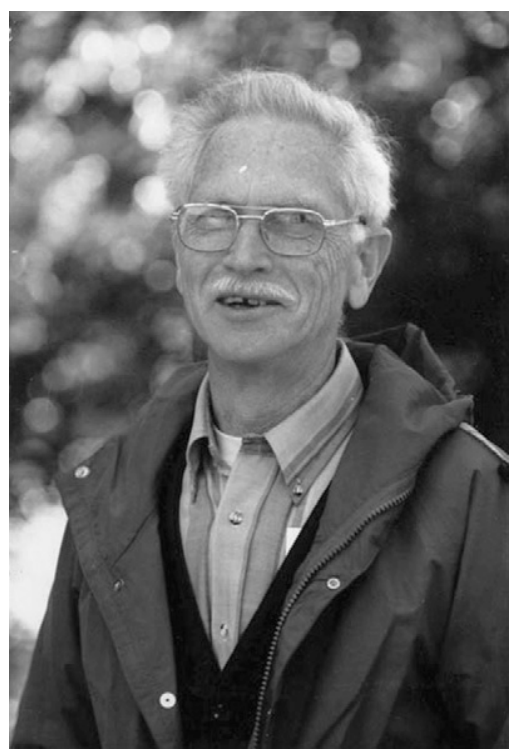

three years later. In 1968 he was appointed chairman of the Department of Botany and Plant Sciences, a post he held for the next seven years.

His service work did not end with his chairmanship. An Academic Senate colleague once estimated that Dr. Soost "must have spent about 2 to 3 days every week during the academic year on committee duties," going on to rank him "among the best (committee) chairs I have ever served under." During one year (1977-78) Dr. Soost served on 24 committees, chairing four of them.

He continued his active life after he and his wife, Jean, moved to Inverness, CA. Dr. Soost was an honored Fellow of the California Native Plant Society and a dedicated volunteer researcher with the Pt. Reyes National Seashore rare plant monitoring group.

Dr. Soost is survived by his wife of 59 years, Jean Soost of Inverness, daughters Anita Soost, Janet Clinton, and Elaine Soost, and four grandchildren, Stacy Clinton, Brian Clinton, Soquel Schafer, and Simon Schafer.

A memorial service was held on 4 Apr. 2009, at the Dance Palace Community Center in Point Reyes Station, CA. Donations in his memory may be made to the Marin Chapter of the California Native Plant Society ["CNPS Marin" c/o Daniel Kushner, 201 Ross St., San Rafael, CA 94901], the Environmental Action Committee of West Marin [http://www.eacmarin.org/], or the UCR Foundation Citrus Variety Collection Endowed Fund [www.citrusvariety.ucr.edu]

Reprinted with permission of the University of California-Riverside.

\section{Teddy E. Morelock}

Dr. Teddy E. Morelock, 65, of Fayetteville died Saturday, 18 Apr. 2009 at his home. He was born 13 June 1943 in Fayetteville, AR, to Ted and Fanny Hembree Morelock. He was a member of the Church of Christ. He was preceded in death by his wife of 34 years, Jane M. Morelock, on 4 Jan. 1999, his parents and one sister, Joan Little.

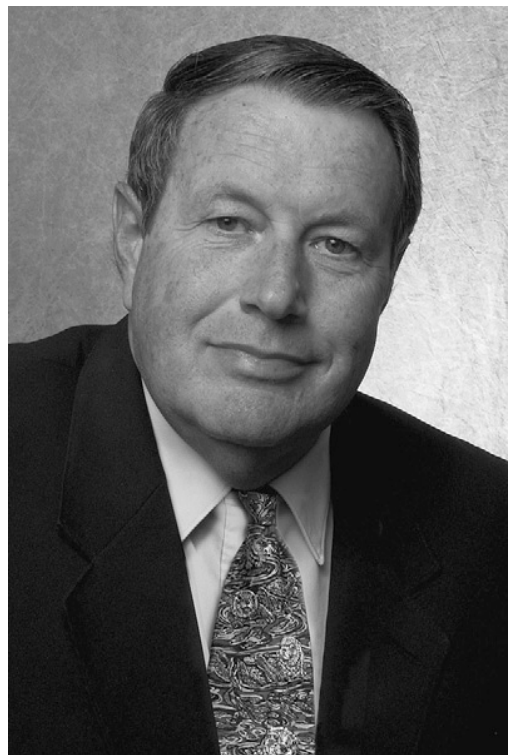

Dr. Morelock graduated from Greenland High School, received his BSA and MS in Horticulture from the University of Arkansas (UA), and his PhD in Plant Breeding and Genetics from the University of Wisconsin. He returned to UA in 1974 as an Assistant Professor in the Department of Horticulture. He served as Associate Professor and Professor and was promoted to University Professor status in 2007. He was an Adjunct Professor for 20 years with Texas A\&M. Dr. Morelock's major research contributions to horticulture involved the development and introduction of improved cowpea, spinach, turnip, and mustard varieties. For more than 20 years his spinach program was the only public sector breeding program in the United States. He was named a Fellow of the American Society of Horticultural Science (ASHS), class of 2004. He received the John W. White Team Research Award from UA in 2005 and 2007. His most recent recognition was the Southern Region-ASHS Distinguished Researcher Award, 2009. He served on numerous university committees and grant writing teams, generating nearly 3.5 million dollars to the UA.

He was an Angus breeder, Advisor of the Year in 2001 for the National Junior Angus Association, and loved helping youth. He had served on the Arkansas Angus Board. He served on several advisory 4-H committees in Washington County, AR.

Survivors include one daughter, Leslie Ann Roye; one granddaughter, Hailey Ann Roye; three brothers-in-law, Herman Jones, Berl Little, and D.W. Morgan; several nieces and nephews and great-nieces and greatnephews, all of Fayetteville, and many friends and associates from all over the world.

The family requests memorials made to the Dr. Teddy Morelock Memorial Scholarship; University of Arkansas, Dale Bumpers College of Agricultural, Food and Life Sciences; Attn: Development Office, E108 AFLS Bldg., Fayetteville, AR 72701.

David Hensley Department of Horticulture University of Arkansas, Fayetteville

\section{Anthony (Tony) Hatch}

An ASHS member for more than 30 years, Anthony H. (Tony) Hatch died in Orem, UT, on 6 Mar. 2009. Tony was born on 23 Oct. 1939 in Colonia Juarez, Chihuahua, Mexico, where he grew up on a fruit farm and completed his high school education. Following graduation from Brigham Young University, Tony obtained his MS in plant science at Utah State University and his doctorate in pomology from Cornell University.

Upon completing his graduate education, Tony joined the faculty of Pennsylvania State University, where he conducted fruit research and worked in the extension program. After a few years in Pennsylvania, Tony accepted a position as superintendent of Colorado State University's western slopes research and 
extension center in Grand Junction. While in Colorado, Tony developed an appreciation for computers and found that they could be used in a variety of ways to help fruit growers raise their crops effectively.

After eight years in Colorado, Tony accepted a position as the extension fruit specialist with Utah State University. Tony continued his work with computers and developed an integrated pest management system designed to help fruit growers reduce pesticide use while still providing effective pest and disease control. Tony also served as the executive secretary of the Utah Horticultural Association for 10 years. Tony's fluent Spanish and fruit science experience made him a valuable member of Utah State University's international program teams that consulted in South America working with government workers and farmers. Tony was also a fine tour guide, taking groups of Utah growers into Mexico to visit the fruit production industry in Chihuahua.

The debilitating effects of Parkinson's disease necessitated Tony taking an early retirement from Utah State University. He is greatly missed by his wife, the former Kathie Burgess, their four children, and many friends and associates.

LAMar ANDERSON Utah State University Logan

\section{Gail Marvin Fosler}

Gail Marvin Fosler passed away peacefully on 17 Apr. 2009 at Westminster Village
North Community in Indianapolis, IN. He had moved to Indianapolis in Dec. 2008 after residing in Champaign, IL, for more than 60 years.

Gail was born on a farm near Milford, NE, to Roy and Florence Fosler on 20 Mar. 1919. There he drove to a one-room schoolhouse by age nine. When he entered the University of Nebraska, Lincoln, at age 17 he also joined the Naval Air Force Reserve. By 1942 he had earned his wings and was called to active duty. As a Naval Air Force navigator in the South Pacific during World War II he earned the Navy Air Medal, the Asiatic-Pacific Campaign Medal, and the American Campaign Medal.

After the war, Gail entered the University of Illinois as a graduate student in biology. He was a member of Gamma Alpha graduate science fraternity and was elected to Phi Beta Kappa. By 1947, he began work as an instructor of floriculture while completing his advanced degree. He later became an associate professor, teaching at the University of Illinois for more than 35 years and ending his career as an associate professor emeritus.

Gail also served as the editor of the Illinois State Florist's Association Bulletin for more than 40 years. He gave numerous talks and published articles throughout his career. Most visibly to Champaign-Urbana residents, he managed the beautiful AllAmerica Trial Gardens at the corner of Florida and Lincoln until he retired in 1984.

Gail and his wife, Norma, moved to Indianapolis in Dec. 2008 to be close to their son, Scott, his wife Julie, and their grand-

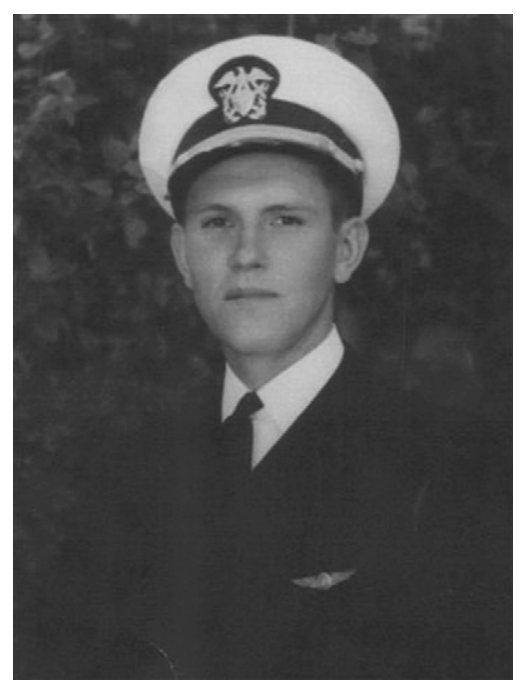

children Drew (10) and Lauren (6). Gail was a beloved husband and father as well as a loving grandfather. In addition to his wife, son, and grandchildren, Gail is survived by an older brother, Don Fosler of Loveland, $\mathrm{CO}$; a younger brother, Merle Fosler of Omaha, NE; and a younger sister, Gene Bobolz of Lincoln, NE.

Memorial services were held 27 Apr. 2009, at the First Presbyterian Church of Urbana, with the Reverend Dr. Philip Gittings officiating. Memorials may be made to the First Presbyterian Church of Urbana.

Condolences to the family may be sent to foslers@comcast.net.

SCOTT FoSLER Inidanapolis, IN 